\title{
Efficient Solid-Phase Synthesis of Trifunctional Probes and Their Application to the Detection of Carbohydrate-Binding Proteins
}

\author{
Myung-ryul Lee, Da-Woon Jung, Darren Williams and Injae Shin*
}

Synthesis of safety-catch linker-coupled acid 1: To a stirred solution of tert-butyl succinate monoester $(0.3 \mathrm{~g}, 1.7 \mathrm{mmol})$ in dry THF was added 1,1 '-carbonyldiimidazole (0.42 g, $2.61 \mathrm{mmol})$. After $15 \mathrm{~min}$, methyl 4-sulfamoylbutyrate (0.62 g, $3.44 \mathrm{mmol})$ and DBU $(0.39 \mathrm{~g}, 2.61 \mathrm{mmol})$ was added to the reaction mixture. After stirring for $24 \mathrm{~h}$ at room temperature, the reaction mixture was concentrated in vacuo. The residue was purified by flash column chromatography (1:1 hexane/EtOAc) to give sulfonamide in $30 \%$ yield as an oil: ${ }^{1} \mathrm{H}$ NMR $\left(250 \mathrm{MHz}, \mathrm{CDCl}_{3}\right) \delta 9.44(\mathrm{~s}, 1 \mathrm{H}), 3.69(\mathrm{~s}, 3 \mathrm{H}), 3.50$ (t, 2 $\mathrm{H}, J=7.9 \mathrm{~Hz}$ ), 2.61 (s, $4 \mathrm{H}), 2.52$ (t, $2 \mathrm{H}, J=7.2 \mathrm{~Hz}), 2.24-2.04$ (m, $2 \mathrm{H}), 1.44$ (s, $9 \mathrm{H})$; ${ }^{13} \mathrm{C}$ NMR $\left(62.9 \mathrm{MHz}, \mathrm{CDCl}_{3}\right) \delta 172.9,172.0,171.5,81.3,51.9,31.7,31.1,29.5,27.9$, 18.6; MALDI-TOF-MS calcd for $\mathrm{C}_{13} \mathrm{H}_{23} \mathrm{NO}_{7} \mathrm{~S}[\mathrm{M}+\mathrm{Na}]^{+} 360.12$, found 360.11 .

To a stirred solution of the synthesized sulfonamide $(0.2 \mathrm{~g}, 0.59 \mathrm{mmol})$ in THF $(1.5$ $\mathrm{mL})$ and $\mathrm{H}_{2} \mathrm{O}(1 \mathrm{~mL})$ was added $1 \mathrm{~N} \mathrm{KOH}(1.18 \mathrm{~mL})$. After $30 \mathrm{~min}$, the reaction mixture was neutralized by using DOWEX 50WX8-400 resin. The resin was removed by filtration and the filtrate was concentrated to give $\mathbf{1}$ in a quantitative yield: ${ }^{1} \mathrm{H}$ NMR $\left(250 \mathrm{MHz}, \mathrm{CDCl}_{3}\right) \delta 10.5(\mathrm{~s}, 2 \mathrm{H}), 3.52(\mathrm{t}, 2 \mathrm{H}, J=7.5 \mathrm{~Hz}), 2.61(\mathrm{~s}, 4 \mathrm{H}), 2.56(\mathrm{t}, 2 \mathrm{H}, J$ $=6.9 \mathrm{~Hz}), 2.23-2.09(\mathrm{~m}, 2 \mathrm{H}), 1.44(\mathrm{~s}, 9 \mathrm{H}) ;{ }^{13} \mathrm{C} \mathrm{NMR}\left(62.9 \mathrm{MHz}, \mathrm{CDCl}_{3}\right) \delta 176.9$, $172.4,171.6,81.8,51.8,31.6,31.1,29.6,27.9$, 18.4; MALDI-TOF-MS calcd for $\mathrm{C}_{12} \mathrm{H}_{21} \mathrm{NO}_{7} \mathrm{~S}[\mathrm{M}+\mathrm{Na}]^{+}$346.10, found 346.09.

Synthesis of BocNH-Ser(BP)-OH (5): To a stirred solution of BocNH-Ser-OH (3.2 $\mathrm{g}, 15.59 \mathrm{mmol})$ in DMF was added sodium hydride $(1.56 \mathrm{~g}, 38.98 \mathrm{mmol})$ at $0{ }^{\circ} \mathrm{C}$. After $15 \mathrm{~min}$ at the same temperature, a solution of 4-bromomethylbenzophenone $(5.15 \mathrm{~g}$, $15.71 \mathrm{mmol}$ ) in DMF was added to the reaction mixture. After $15 \mathrm{~min}$, the reaction was allowed for stirring for $24 \mathrm{~h}$ at room temperature. The reaction was quenched by addition of water, acidified to $\mathrm{pH} 2.0$ and then extracted with EtOAc. The combined organic layers were washed with $\mathrm{H}_{2} \mathrm{O}$ and brine, dried over $\mathrm{MgSO}_{4}$, and concentrated in vacuo. The crude product was dissolved in ether and then cyclohexylamine (1.78 g, $15.59 \mathrm{mmol}$ ) was added. After stirring for $1 \mathrm{~h}$, precipitate was collected by filtration and dried in vacuo. The precipitate was re-dissolved in $\mathrm{CH}_{2} \mathrm{Cl}_{2}$, washed with $1 \mathrm{~N} \mathrm{HCl}, \mathrm{H}_{2} \mathrm{O}$ and brine, dried over $\mathrm{MgSO}_{4}$, and concentrated to give 5 in $60 \%$ yield: ${ }^{1} \mathrm{H}$ NMR (500 
$\left.\mathrm{MHz}, \mathrm{CDCl}_{3}\right) \delta$ 7.85-7.33 (m, $\left.10 \mathrm{H}\right), 5.55(\mathrm{~d}, 1 \mathrm{H}, J=7.5 \mathrm{~Hz}), 4.67-4.56(\mathrm{~m}, 2 \mathrm{H}), 4.55-$ $4.50(\mathrm{~m}, 1 \mathrm{H}), 3.97$ (d, $2 \mathrm{H}, J=7.5 \mathrm{~Hz}), 3.78$ (d, $2 \mathrm{H}, J=7.5 \mathrm{~Hz}), 1.44(\mathrm{~s}, 9 \mathrm{H}) ;{ }^{13} \mathrm{C}$ NMR $\left(125 \mathrm{MHz}, \mathrm{CDCl}_{3}\right) \delta 196.6,174.2,155.8,142.4,137.5,136.9,132.5,130.3,130.0$, $128.3,127.1,80.4,72.7,70.3,53.9,28.3$; MALDI-TOF-MS calcd for $\mathrm{C}_{22} \mathrm{H}_{25} \mathrm{NO}_{6}$ $[\mathrm{M}+\mathrm{Na}]^{+} 422.17$, found 422.16 .

General Procedure for Synthesis of Tag-tether- $\mathrm{NH}_{2}$ : To a stirred solution of Cy3, Cy5 or biotin (60 mmol) in DMF was added EDC (120 mmol), DMAP (120 mmol) and $\mathrm{N}$-Boc-3,6-dioxa-1,8-octanediamine $(120 \mathrm{mmol})$. After stirring for $10 \mathrm{~h}$ at room temperature, the reaction mixture was directly purified by preparative RP-HPLC with a gradient of $5-100 \% \mathrm{CH}_{3} \mathrm{CN}$ in water $(0.1 \%$ TFA) over $85 \mathrm{~min}$.

Cy5-tether-NHBoc: ${ }^{1} \mathrm{H}$ NMR (500 MHz, $\left.\mathrm{CD}_{3} \mathrm{OD}\right) \delta$ 8.16-8.28 (m, $\left.2 \mathrm{H}\right)$, 7.54-7.16 $(\mathrm{m}, 8 \mathrm{H}), 6.62(\mathrm{t}, 1 \mathrm{H}, J=12 \mathrm{~Hz}), 6.28(\mathrm{~d}, 1 \mathrm{H}, J=5 \mathrm{~Hz}), 6.25(\mathrm{~d}, 1 \mathrm{H}, J=5 \mathrm{~Hz}), 4.10$ $(\mathrm{t}, 2 \mathrm{H}, J=6.5 \mathrm{~Hz}), 3.62(\mathrm{~s}, 3 \mathrm{H}), 3.56(\mathrm{~s}, 4 \mathrm{H}), 3.51(\mathrm{t}, 2 \mathrm{H}, J=5 \mathrm{~Hz}), 3.47(\mathrm{t}, 2 \mathrm{H}, J=$ $5 \mathrm{~Hz}$ ), 3.35 (t, $2 \mathrm{H}, J=5 \mathrm{~Hz}$ ), 3.19 (t, $2 \mathrm{H}, J=5 \mathrm{~Hz}$ ), 2.30 (t, $2 \mathrm{H}, J=6 \mathrm{~Hz}$ ), 1.87-1.63 $(\mathrm{m}, 16 \mathrm{H}), 1.40(\mathrm{~s}, 9 \mathrm{H}) ;{ }^{13} \mathrm{C}$ NMR $\left(125 \mathrm{MHz}, \mathrm{CD}_{3} \mathrm{OD}\right) \delta 175.4,174.4,155.4,144.1$, $143.5,142.5,142.4,129.7,126.6,126.2,126.1,123.3,123.2,111.9,111.8,104.4,104.2$, 80.0, 71.2, 71.0, 70.5, 50.4, 44.6, 41.1, 40.2, 36.2, 31.5, 28.7, 27.9, 27.7, 24.0; MALDITOF-MS calcd for $\mathrm{C}_{42} \mathrm{H}_{59} \mathrm{~N}_{4} \mathrm{O}_{5}[\mathrm{M}]^{+} 699.45$, found 699.45.

Cy3-tether-NHBoc: ${ }^{1} \mathrm{H}$ NMR $\left(500 \mathrm{MHz}, \mathrm{CD}_{3} \mathrm{OD}\right) \delta 8.55(\mathrm{t}, 1 \mathrm{H}, J=13.5 \mathrm{~Hz})$, 7.59-7.25 (m, $8 \mathrm{H}), 6.45$ (s, $1 \mathrm{H}), 6.43(\mathrm{~s}, 1 \mathrm{H}), 4.16$ (t, $2 \mathrm{H}, J=6.5 \mathrm{~Hz}), 3.69$ (s, $3 \mathrm{H})$, $3.56(\mathrm{~s}, 4 \mathrm{H}), 3.52(\mathrm{t}, 2 \mathrm{H}, J=5 \mathrm{~Hz}), 3.45(\mathrm{t}, 2 \mathrm{H}, J=5.5 \mathrm{~Hz}), 3.36(\mathrm{t}, 2 \mathrm{H}, J=5 \mathrm{~Hz})$, $3.18(\mathrm{t}, 2 \mathrm{H}, J=5.5 \mathrm{~Hz}), 2.31(\mathrm{t}, 2 \mathrm{H}, J=6 \mathrm{~Hz}), 1.91-1.73(\mathrm{~m}, 16 \mathrm{H}), 1.40(\mathrm{~s}, 9 \mathrm{H}) ;{ }^{13} \mathrm{C}$ NMR (125 MHz, CD 3 OD) $\delta 176.7,175.9,175.4,152.1,144.0,143.3,142.1,142.0$, $129.9,126.8,126.7,123.5,123.3,112.4,112.2$, 103.8, 103.6, 80.0, 71.2, 71.0, 70.5, 50.6, 44.9, 41.1, 40.2, 36.2, 31.7, 28.7, 28.3, 28.1, 27.8, 23.9; MALDI-TOF-MS calcd for $\mathrm{C}_{40} \mathrm{H}_{57} \mathrm{~N}_{4} \mathrm{O}_{5}[\mathrm{M}]^{+}$673.43, found 673.43.

Biotin-tether-NHBoc: ${ }^{1} \mathrm{H}$ NMR $\left(500 \mathrm{MHz}, \mathrm{CD}_{3} \mathrm{OD}\right) \delta 4.55-4.51(\mathrm{~m}, 1 \mathrm{H}), 4.37-$ 4.33 (m, $1 \mathrm{H}), 3.64$ (s, $4 \mathrm{H}), 3.57$ (t, $2 \mathrm{H}, J=5 \mathrm{~Hz}), 3.54$ (t, $2 \mathrm{H}, J=5.5 \mathrm{~Hz}), 3.39$ (t, 2 $\mathrm{H}, J=5.5 \mathrm{~Hz}), 3.25$ (t, $2 \mathrm{H}, J=5.5 \mathrm{~Hz}), 2.95(\mathrm{dd}, 1 \mathrm{H}, J=4.5,13 \mathrm{~Hz}), 2.74(\mathrm{~d}, 1 \mathrm{H}, J=$ $12.5 \mathrm{~Hz}), 2.25$ (t, $2 \mathrm{H}, J=7.5 \mathrm{~Hz}), 1.85-1.56(\mathrm{~m}, 4 \mathrm{H}), 1.40(\mathrm{~s}, 11 \mathrm{H}) ;{ }^{13} \mathrm{C}$ NMR $(125$ $\left.\mathrm{MHz}, \mathrm{CD}_{3} \mathrm{OD}\right) \delta 176.0,165.9,158.2,80.0,71.2,71.0,70.5,63.3,61.6,56.9,41.1,41.0$, 40.2, 36.6, 29.6, 29.4, 28.7, 26.7; MALDI-TOF-MS calcd for $\mathrm{C}_{21} \mathrm{H}_{38} \mathrm{~N}_{4} \mathrm{O}_{6} \mathrm{~S}[\mathrm{M}+\mathrm{Na}]^{+}$ 497.25, found 497.24.

A solution of Cy3-tether-NHBoc, Cy5-tether-NHBoc or Biotin-tether-NHBoc (30 mmol) in $75 \%$ TFA in $\mathrm{CH}_{2} \mathrm{Cl}_{2}$ was stirred for $1.5 \mathrm{~h}$, and then the reaction mixture was 
concentrated in vacuo. The concentration step was repeated several times to remove residual TFA, and then the crude product was used for the next reaction without further purification.

General Procedure for Solid Phase Synthesis of Monovalent Carbohydrate Probes: A solution of 1 ( $0.097 \mathrm{~g}, 0.3 \mathrm{mmol})$, BOP (0.132 mg, $0.3 \mathrm{mmol})$, HOBt (0.046 $\mathrm{g}, 0.3 \mathrm{mmol})$ and NEM $(0.057 \mathrm{~g}, 0.5 \mathrm{mmol})$ in DMF was added to the PS-PEG amine resin $(0.1 \mathrm{mmol})$. After shaking for $12 \mathrm{~h}$, the resin was filtered and washed with DMF. $t$ Butyl group in the resin 2 was removed by treatment with 75\% TFA in $\mathrm{CH}_{2} \mathrm{Cl}_{2}(15 \mathrm{~min}$ $x$ 2). A solution of 4,7,10-trioxa-1-13-tridecanediamine (3, $0.22 \mathrm{~g}, 1 \mathrm{mmol})$ and BOP $(0.22 \mathrm{~g}, 0.5 \mathrm{mmol})$ in DMF was added to the resin. After shaking for $6 \mathrm{~h}$, the resin was filtered and washed with DMF.

A solution of $5(30 \mu \mathrm{mol}), \mathrm{BOP}(30 \mu \mathrm{mol}), \mathrm{HOBt}(30 \mu \mathrm{mol})$ and $\mathrm{NEM}(50 \mu \mathrm{mol})$ in DMF was added to the amine terminated resin $4(10 \mu \mathrm{mol})$. After shaking for $12 \mathrm{~h}$, the resin was filtered and washed with DMF. Boc group in the resin 6 was removed by treatment with $75 \%$ TFA in $\mathrm{CH}_{2} \mathrm{Cl}_{2}$ (15 min $\left.\mathrm{x} 2\right)$. A solution of succinic anhydride $(0.3$ $\mathrm{mmol})$ and NEM (0.6 mmol) in DMF was added to the resin. After shaking for $12 \mathrm{~h}$, the resin was filtered and washed with DMF. A solution of 2-aminoethyl $\alpha$-Lfucopyranoside or 2-aminoethyl $\alpha$-D-mannopyranoside $(90 \mu \mathrm{mol})$, and BOP $(90 \mu \mathrm{mol})$ in DMF was added to the resin. After shaking for $12 \mathrm{~h}$, the resin was filtered and washed with DMF. A solution of iodoacetonitrile $(0.25 \mathrm{mmol})$, DIEA $(50 \mu \mathrm{mol})$ in NMP was added to the resin 7. After shaking for $12 \mathrm{~h}$, the resin was filtered and washed with NMP. A solution of Cy3-tether- $\mathrm{NH}_{2}(50 \mu \mathrm{mol})$ and NEM $(50 \mu \mathrm{mol})$ in NMP was added to the resin. After shaking for $12 \mathrm{~h}$, the resin was filtered and washed with DMF. The combined filtrate was concentrated in vacuo and directly purified by preparative RPHPLC with a gradient of 5-100\% $\mathrm{CH}_{3} \mathrm{CN}$ in water (0.1\% TFA) over $85 \mathrm{~min}$.

Cy3-mono-Fuc (8): MALDI-TOF-MS Calcd for $\mathrm{C}_{78} \mathrm{H}_{109} \mathrm{~N}_{8} \mathrm{O}_{18}[\mathrm{M}]^{+} 1445.78$, found 1445.78 .

Cy3-mono-Man (9): MALDI-TOF-MS Calcd for $\mathrm{C}_{78} \mathrm{H}_{109} \mathrm{~N}_{8} \mathrm{O}_{19}[\mathrm{M}]^{+}$1461.78, found 1461.79 .

General Procedure for Solid Phase Synthesis of Trivalent Carbohydrate Probes: A solution of FmocLys(Boc)OH $(30 \mu \mathrm{mol})$, BOP $(30 \mu \mathrm{mol})$, HOBt $(30 \mu \mathrm{mol})$ and NEM $(50 \mu \mathrm{mol})$ in DMF was added to the amine resin $4(10 \mu \mathrm{mol})$. After shaking for $12 \mathrm{~h}$, the resin was filtered and washed with DMF. Fmoc group in the resin 10 was removed by treatment with $20 \%$ piperidine in DMF and then washed with DMF. A 
solution of FmocLys(Fmoc)OH $(30 \mu \mathrm{mol})$, BOP $(30 \mu \mathrm{mol})$, HOBt $(30 \mu \mathrm{mol})$ and NEM $(50 \mu \mathrm{mol})$ in DMF was added to the resin. After shaking for $12 \mathrm{~h}$, the resin was filtered and washed with DMF. Boc group in the resin 11 was removed by treatment with $75 \%$ TFA in $\mathrm{CH}_{2} \mathrm{Cl}_{2}(15 \mathrm{~min} \times 2)$. A solution of $5(30 \mu \mathrm{mol})$, BOP $(30 \mu \mathrm{mol})$, HOBt $(30$ $\mu \mathrm{mol})$ and NEM $(50 \mu \mathrm{mol})$ in DMF was added to the resin. After shaking for $12 \mathrm{~h}$, the resin was filtered and washed with DMF. Boc group in the resin 12 was removed by treatment with $75 \%$ TFA in $\mathrm{CH}_{2} \mathrm{Cl}_{2}(15 \mathrm{~min} \times 2)$ and then Fmoc group was deprotected by treatment with $20 \%$ piperidine in DMF. A solution of succinic anhydride $(0.3 \mathrm{mmol})$ and NEM (0.6 mmol) in DMF was added to the resin. After shaking for $12 \mathrm{~h}$, the resin was filtered and washed with DMF. A solution of 2-aminoethyl $\alpha$-L-fucopyranoside or 2-aminoethyl $\alpha$-D-mannopyranoside $(90 \mu \mathrm{mol})$, and BOP $(90 \mu \mathrm{mol})$ in DMF was added to the resin. After shaking for $12 \mathrm{~h}$, the resin was filtered and washed with DMF. A solution of iodoacetonitrile $(0.25 \mathrm{mmol})$, DIEA $(50 \mu \mathrm{mol})$ in NMP was added to the resin 13. After shaking for $12 \mathrm{~h}$, the resin was filtered and washed with NMP. A solution of Cy3-tether- $\mathrm{NH}_{2}, \mathrm{Cy} 5$-tether- $\mathrm{NH}_{2}$ or Biotin-tether- $\mathrm{NH}_{2}(50 \mu \mathrm{mol})$ and NEM (50 $\mu \mathrm{mol}$ ) in NMP was added to the resin. After shaking for $12 \mathrm{~h}$, the resin was filtered and washed with DMF. The combined filtrate was concentrated in vacuo and directly purified by preparative RP-HPLC with a gradient of $5-100 \% \mathrm{CH}_{3} \mathrm{CN}$ in water $(0.1 \%$ TFA) over $85 \mathrm{~min}$.

Biotin-tri-Fuc (14): MALDI-TOF-MS Calcd for $\mathrm{C}_{95} \mathrm{H}_{152} \mathrm{~N}_{14} \mathrm{O}_{35} \mathrm{~S}[\mathrm{M}+\mathrm{Na}]^{+}$2104.02, found 2104.02.

Cy3-tri-Fuc (15): MALDI-TOF-MS Calcd for $\mathrm{C}_{114} \mathrm{H}_{171} \mathrm{~N}_{14} \mathrm{O}_{34}[\mathrm{M}]^{+} 2280.20$, found 2280.20 .

Cy5-tri-Fuc (16): MALDI-TOF-MS Calcd for $\mathrm{C}_{116} \mathrm{H}_{173} \mathrm{~N}_{14} \mathrm{O}_{34}[\mathrm{M}]^{+}$2306.22, found 2306.22.

Cy3-tri-Man (17): MALDI-TOF-MS Calcd for $\mathrm{C}_{114} \mathrm{H}_{171} \mathrm{~N}_{14} \mathrm{O}_{37}[\mathrm{M}]^{+}$2328.19, found 2328.17 .

Biotin-tri-Man (18): MALDI-TOF-MS Calcd for $\mathrm{C}_{95} \mathrm{H}_{152} \mathrm{~N}_{14} \mathrm{O}_{38} \mathrm{~S} \quad[\mathrm{M}+\mathrm{Na}]^{+}$ 2152.01, found 2152.01.

General Procedure for Protein Labeling by Carbohydrate Probes. Carbohydrate probes $(0.2 \mu \mathrm{L})$ dissolved in DMSO were preincubated with lectin $(19.8 \mu \mathrm{L})$ in PBS $(\mathrm{pH} 7.2)$ at $37^{\circ} \mathrm{C}$. After $20 \mathrm{~min}$, the reaction mixture was irradiated with a handheld UV lamp $(12 \mathrm{~W}, 365 \mathrm{~nm})$ at $4{ }^{\circ} \mathrm{C}$ for $5-30 \mathrm{~min}$. The reaction was terminated by adding $2 \mathrm{x}$ SDS-PAGE loading buffer and then heating at $90{ }^{\circ} \mathrm{C}$ for $3 \mathrm{~min}$. The sample was separated by $12 \%$ SDS-PAGE and then fluorescence intensity was analyzed by a 
Scannarray 5000 from Packardbiochip. Proteins were also visualized by silver staining (Amersham) or Coomassie blue staining, as required.

Detection sensitivity. Biotin-tri-Fuc (14, $200 \mathrm{nM})$ or Cy3-tri-Fuc $(\mathbf{1 5}, 200 \mathrm{nM})$ was incubated with various amounts of AA $(0,0.14,0.4,1.2,3.7,11,33,100$ and $300 \mathrm{ng})$ and then irradiated. For fluorescence detection, the reaction mixtures were treated as described above. For Western blot analysis, Biotin-tri-Fuc-labeled protein separated by $12 \%$ SDS-PAGE was transferred onto nitrocellulose membrane and then treated with horseradish peroxidase-conjugated streptavidin. The treated membrane was visualized by using the ECL kit from Amersham-Pharmacia Biotech.

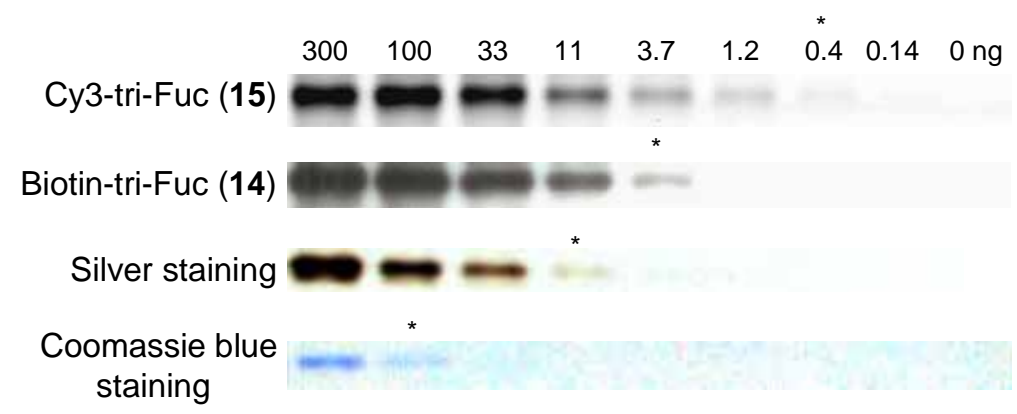


Protein labeling by monovalent $(8,9)$ and trivalent carbohydrate probes $(15,17)$

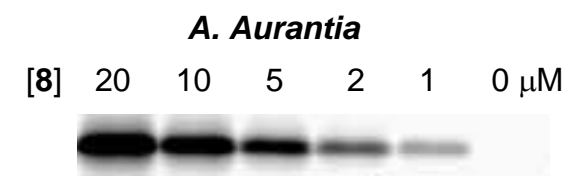

[15] $\begin{array}{llllllll}1 & 0.2 & 0.05 & 0.01 & 0.002 & 0 \mu \mathrm{M}\end{array}$

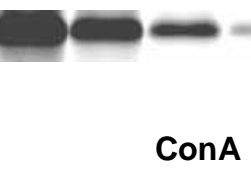

[9] $20 \quad 10 \quad 5 \quad 20 \quad 1 \quad 0 \mu M$

[17] $20 \quad 10 \quad 5 \quad 2 \quad 1 \quad 0 \mu \mathrm{M}$ 


\section{Quantitation of AA labeling under two different conditions}

(a)

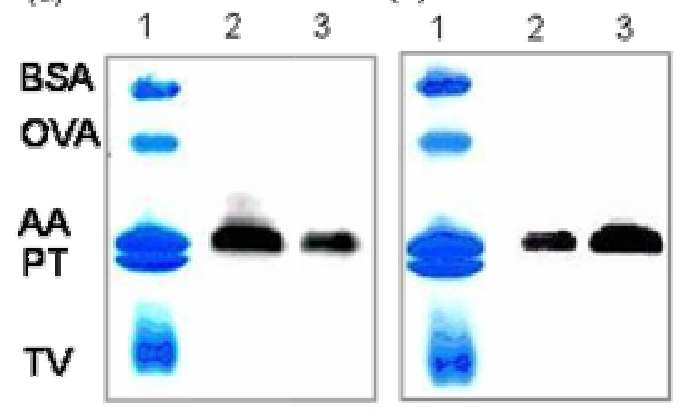

(c)

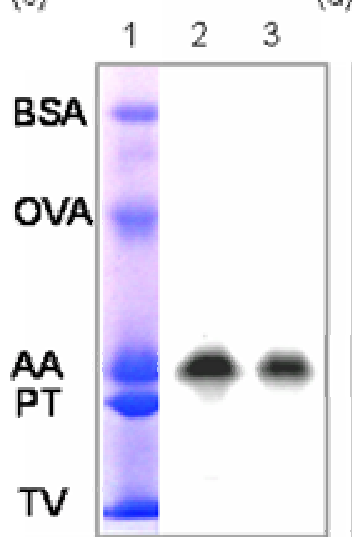

(d)

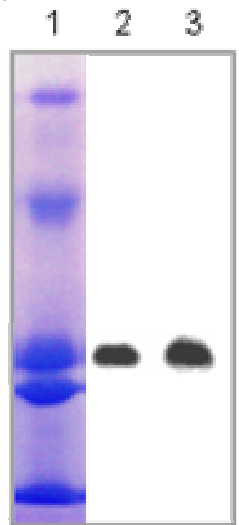

(a) The mixture of five proteins containing $800 \mathrm{ng}$ of AA or $200 \mathrm{ng}$ of AA was separately incubated with Cy3-tri-Fuc (15) or Cy5-tri-Fuc (16), respectively, and then irradiated. The mixtures were combined and subjected to protein gel separation (the ratio of fluorescence intensities of $\mathrm{Cy} 3$ and $\mathrm{Cy} 5=4: 1$ ).

(b) The mixture of five proteins containing $200 \mathrm{ng}$ of AA or $800 \mathrm{ng}$ of AA was separately incubated with Cy3-tri-Fuc (15) or Cy5-tri-Fuc (16), respectively, and then irradiated. The mixtures were combined and subjected to protein gel separation (the ratio of fluorescence intensities of $\mathrm{Cy} 3$ and $\mathrm{Cy} 5=1: 4$ ).

(c) The mixture of five proteins containing $200 \mathrm{ng}$ of AA or $100 \mathrm{ng}$ of AA was separately incubated with Cy3-tri-Fuc (15) or Cy5-tri-Fuc (16), respectively, and then irradiated. The mixtures were combined and subjected to protein gel separation (the ratio of fluorescence intensities of $\mathrm{Cy} 3$ and $\mathrm{Cy} 5=2: 1$ ).

(d) The mixture of five proteins containing $100 \mathrm{ng}$ of AA or $200 \mathrm{ng}$ of AA was separately incubated with Cy3-tri-Fuc (15) or Cy5-tri-Fuc (16), respectively, and then irradiated. The mixtures were combined and subjected to protein gel separation (the ratio of fluorescence intensities of $\mathrm{Cy} 3$ and $\mathrm{Cy} 5=1: 2$ ).

(Lane 1; Coomassie blue staining, lane 2; Cy3 fluorescence detection, lane 3; Cy5 fluorescence detection) 